\title{
Advanced Power Transmission System
}

\author{
Rafea M. Abd El-Maksoud, Nazih N. Bayomi ${ }^{1}$ and Mohamed A. Saleh ${ }^{2}$ \\ Faculty of Engineering, Mataria, Helwan University, Cairo, Egypt, ${ }^{1}$ King Abdulaziz \\ University, Jeddah, Kingdom of Saudi Arabia, and Industrial Sales, Technical support \\ \& Training Engineer, Chevron Egypt Lubricants, Cairo, Egypt \\ brainandspirit@yahoo.com
}

\begin{abstract}
Different researches are adopted to modify and enhance automatic transmission by every means. Whereas, torque converter that represents the most important component in such transmission suffers from some problems that are not completely solved. In this paper, power transmission system is herein introduced as a unique power transmission system that is not affected by torque converter problems. This power transmission operates with power splitting concept and is composed of conventional torque converter connected to planetary sets. Three clutches are used to shift the operating modes and unique positive displacement hydraulic couplings are utilized to regulate performance in power paths. Also, a modified model used to predict torque converter performance is utilized with planetary gear kinetics to assess the transmission performance. Moreover, the present system operates with high performance. Unlike the automatic transmission that operates in line, the present system operates with infinity number of operational bands for each engine speed.
\end{abstract}

\section{Introduction}

Many researches adopted to study and enhance torque converter due to its vast applications especially in vehicles. Several researchers ${ }^{[1-6]}$ studied it to enhance its operation. However, different developments in torque converter are limited by its operational range and problems related to outranged operation in low and high speed ratios.

On the other side, power splitting concept is a well known trend used to enhance low performance systems as well as systems based on 
power transfer through friction. This is usually accomplished by splitting the power into two portions. The first power portion passes through such systems while the other portion is bypassed mechanically. Thereafter, the two power portions are combined together with different output characteristic (Torque and speed) ${ }^{[7]}$. Vast studies have been carried out to illustrate its merits ${ }^{[7-14]}$. Continuous variable transmission and infinity variable transmission are wide application scale of this concept in vehicles. Applying power splitting concept to the torque converter for enhancing its operation is presented by Abd El-Maksoud ${ }^{[7]}$ and Saleh ${ }^{[14]}$.

In the present work, it is proposed to introduce new high performance power transmission system where torque converter is one of its main constitutions. The system operation is based on power splitting concept where only portion of power passes through the torque converter making its problems insignificant. Such system with its new construction of planetary gears introduces a whole continuous variable transmission unit controlled by unique coupling, vane coupling, presented in Abd ElMaksoud $^{[7]}$. A simplified model for torque converter performance prediction with planetary kinematics is introduced to assess the system. To demonstrate its merits, a modified model used to predict torque converter performance is utilized with planetary gear kinetics. Comparison is presented with automatic transmission to assess its performance.

\section{System Layout}

The system layout presented in this paper is composed of a blend of two configurations to introduce two modes of power splitting operation; one at low speed and the other at high speed. Figure 1 demonstrates the first configuration that is composed of conventional torque converter, planetary gear set which are reaction planetary set and output planetary set. This configuration is configured in such a way that it is composed of two simple planetary sets. The torque converter is the power splitter that its two power paths are controlled via the vane coupling then power is recombined with the two planetary sets. The reaction set (casing planetary set) has its ring gear fixed and its sun gear is attached to the converter casing through vane coupling and its planetary carrier is the output (input to the second planetary gear set). The output planetary set (turbine planetary set) has its sun gear is mechanically engaged to the 
turbine output shaft through the vane coupling. The ring gear (input ring gear) of the output planetary set is attached to the output carrier from the first planetary gear set. The output shaft is connected to the second planet carrier of planetary gear set. The red lines represent the power flow paths and directions.

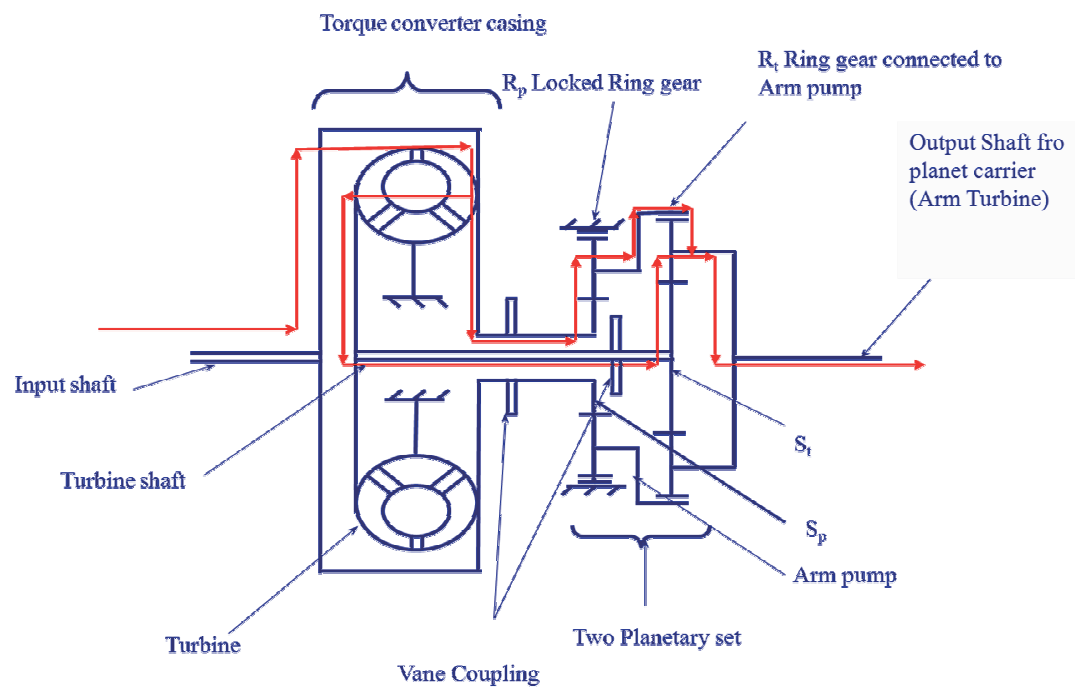

Fig. 1. The first configuration.

The second configuration consists mainly of torque converter, planetary gear sets, and the vane coupling is shown in Fig. 2. The torque converter is the splitter unit. The reaction planetary set (casing planetary set) has its arm fixed and its sun gear is attached to the converter casing through the vane coupling, and its ring gear is the output (input to the output planetary gear set). The output planetary (turbine planetary set) set has its sun gear is mechanically engaged to the turbine output shaft through vane coupling. Its planet carrier is connected to the second ring gear of the planetary gear set.

The whole power transmission system is illustrated in Fig. 3. This is blend of both the first and second configurations to combine the benefits with a start mode of operation. The present system is introduced to be flexible enough to fit and change according to the load and speed requirements of the equipment in use with this configuration. The present system implements three clutched mechanisms to enable switching between the three operating modes that are; torque converter is directly attached to reduction gear (not included in the plot), the first 
configuration and finally the second configuration. Another solution for the reduction gets clutch and vane coupling attached to it, is that the vane coupling of the first and second configurations should be operated in the unlocking mode. One of the three clutches is locked to operate the system in one of the three modes. When the three clutches are disengaged, the transmission is in the neutral condition.

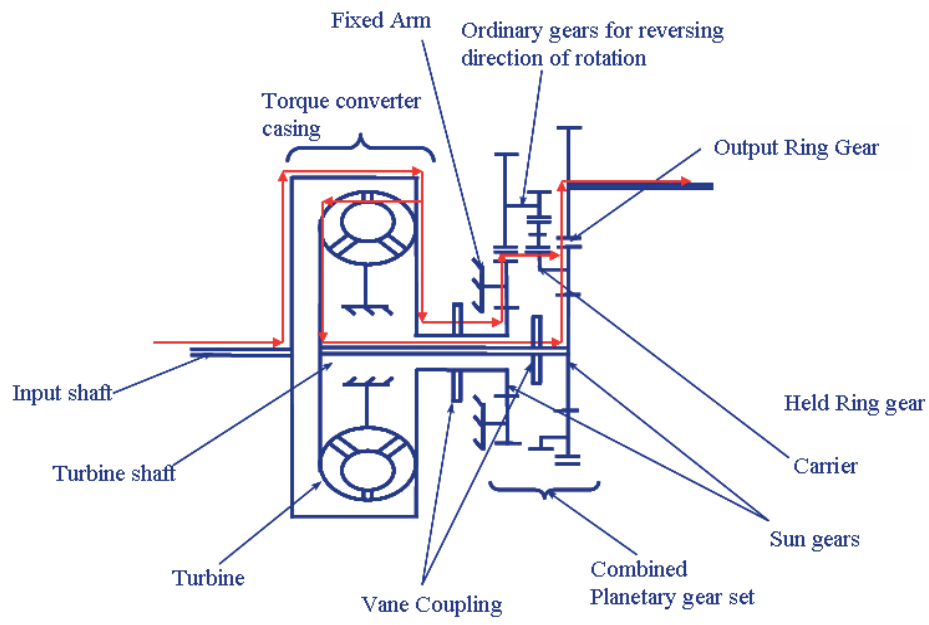

Fig. 2. The second configuration.

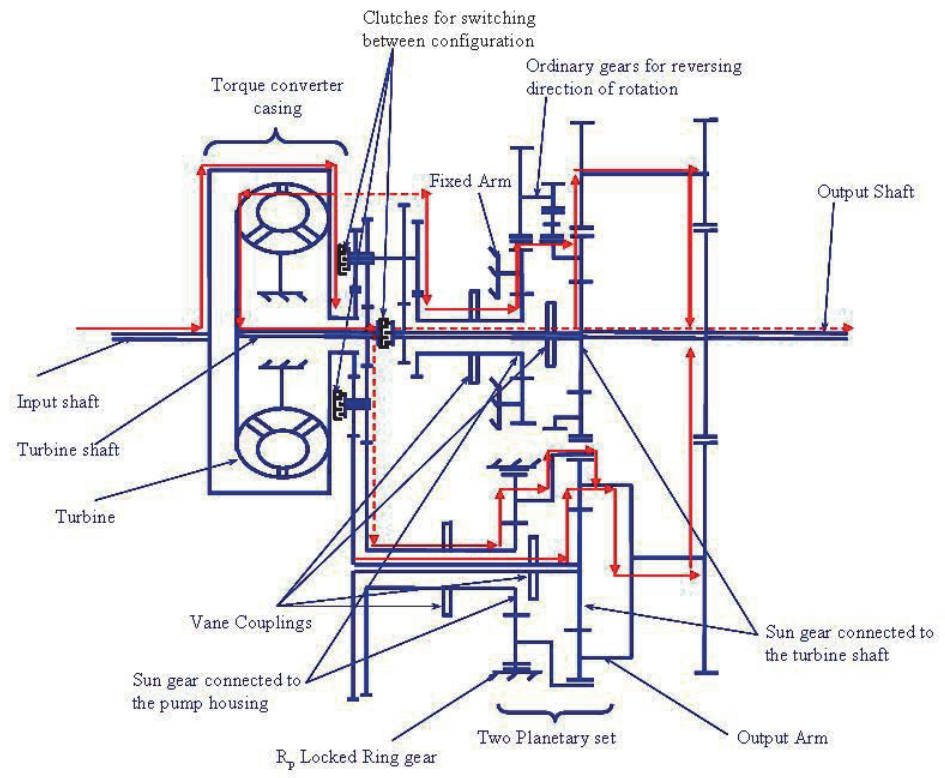

Fig. 3. The whole power system. 
Vane coupling introduced in this work is typically presented in the finding of Abd El-Maksoud ${ }^{[7]}$. Utilizing such coupling in the torque converter system is to regulate torque and thus power in the power paths. This coupling has typical components of axisymmetric vane pump that is composed mainly of rotor, vanes, casing, as shown in Fig. 4. The only distinct feature is that the casing is connected to another shaft.

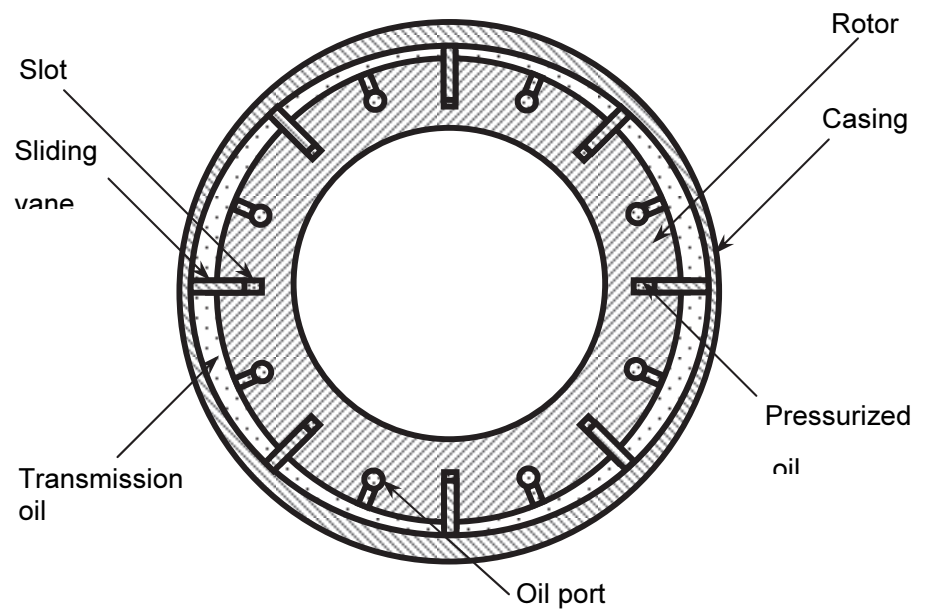

Fig. 4. Vane coupling construction, Abd El-Maksoud ${ }^{[7]}$.

During torque transmission, preventing oil from discharge from the oil ports results in no relative rotation between the rotor and the casing. In this case, the coupling operates in the locking mode leading the released case to spin with the rotor together according to the transmitted torque. For less torque transmission demand, the build-up pressure inside the coupling is reduced. This causes the casing to spin slower than the rotor and some oil is discharged from this coupling because of the relative motion between the rotor and casing. Thereafter, when the required transmitted torque is established, no relative motion appears between the rotor and the casing. If there is no build-up pressure, the vane coupling is idled or fully unlocked. Changing the build-up pressure is accomplished by electronically controlled hydraulic system attached to the vane couplings. This alters their torque capacities and results in transmitting a particular torque according to the build-up pressure. Consequently, the vane couplings are used to vary the torque and power in each of the power paths according to the demand requirements and controls the power portion transferred mechanically. 


\section{Modeling and Kinetics}

The mathematical treatment presented herein is based previous study by Eksergian ${ }^{[1]}$ and modified by Saleh ${ }^{[14]}$, the torque done on the fluid by the pump impeller is:

$$
\mathrm{T}_{\mathrm{p}}=\rho \mathrm{Q}\left(\omega_{\mathrm{p}} \mathrm{R}_{\mathrm{pe}}^{2}+\left[\frac{\mathrm{R}_{\mathrm{pe}} \tan \beta_{\mathrm{pe}}}{\mathrm{A}_{\mathrm{pe}}}-\frac{\mathrm{R}_{\mathrm{se}} \tan \beta_{\mathrm{se}}}{\mathrm{A}_{\mathrm{se}}}\right] \mathrm{Q}\right)
$$

Where $\mathrm{A}$ is the area, $\mathrm{Q}$ is the flow rate flow rate passing through the torque converter, $\mathrm{R}$ is the pump outer radius, $\omega$ is the angular velocity, $\beta$ is the blade angle, $\rho$ is the fluid density, while the subscripts $p$ and $s$ denote the pump and stator and the subscript e denotes the outlet condition. According to Dong ${ }^{[3]}$, the flow rate is expressed as:

$$
\mathrm{Q}=\mathrm{k} \sqrt{\left(\mathrm{R}_{\mathrm{pe}}^{2}-\mathrm{R}_{\mathrm{se}}^{2}\right)\left(\mathrm{N}_{\mathrm{p}}^{2}-\mathrm{N}_{\mathrm{t}}^{2}\right)}
$$

Where $\mathrm{k}$ is correction factor, the value of this factor is assumed to have approximately 1.1 in order to make the model fits the experimental work, $\mathrm{N}$ is the rotational speed. Using the non-dimensional volume flow rate coefficient $\left(\mathrm{C}_{\mathrm{f}}\right)$, the physical meaning of this parameter is the ratio of the averaged normal velocity at the pump exit to the rotating speed of the pump blade exit tip.

$$
\mathrm{C}_{\mathrm{f}}=\frac{\mathrm{Q}}{\mathrm{A}_{\mathrm{pe}} \mathrm{U}_{\max }}=\frac{2 \mathrm{Q}}{\mathrm{A}_{\mathrm{pe}} \omega_{\mathrm{p}} \mathrm{D}}
$$

Where $\mathrm{D}$ is wheel diameter, and $\mathrm{U}_{\max }=0.5 \omega_{\mathrm{p}} \mathrm{D}$, Pump torque could then be written as:

$$
\mathrm{T}_{\mathrm{p}}=\rho \omega_{\mathrm{p}}^{2} \mathrm{R}_{\mathrm{pe}}^{3} \mathrm{~A}_{\mathrm{pe}} \mathrm{C}_{\mathrm{f}}\left(1+\mathrm{C}_{\mathrm{f}} \tan \beta_{\mathrm{pe}}-\frac{\lambda_{\mathrm{r}}}{\lambda_{\mathrm{a}}} \mathrm{C}_{\mathrm{f}} \tan \beta_{\mathrm{se}}\right)
$$

Where the Area ratio $\lambda_{\mathrm{a}}$ and the Radius ratio $\lambda_{\mathrm{r}}$ were defined as:

$$
\lambda_{\mathrm{a}}=\frac{\mathrm{A}_{\mathrm{se}}}{\mathrm{A}_{\mathrm{pe}}}, \lambda_{\mathrm{r}}=\frac{\mathrm{R}_{\mathrm{se}}}{\mathrm{R}_{\mathrm{pe}}}
$$

The angular momentum of the fluid entering the turbine is the angular momentum of the fluid exiting the pump impeller with 
assumption of infinitesimal distance between both rotors; then the angular momentum of the fluid entering the turbine will be:

$$
\rho \mathrm{Q}\left(\omega_{\mathrm{p}} \mathrm{R}_{\mathrm{pe}}+\frac{\mathrm{Q}}{\mathrm{A}_{\mathrm{pe}}} \tan \beta_{\mathrm{pe}}\right) \mathrm{R}_{\mathrm{pe}}
$$

The angular momentum of the fluid exiting the turbine rotor will be:

$$
\rho Q\left(\omega_{\mathrm{t}} \mathrm{R}_{\mathrm{te}}+\frac{\mathrm{Q}}{\mathrm{A}_{\mathrm{te}}} \tan \beta_{\mathrm{te}}\right) \mathrm{R}_{\mathrm{te}}
$$

Therefore, the angular momentum of the fluid exerted on the turbine rotor is:

$$
\mathrm{T}_{\mathrm{t}}=\rho \mathrm{Q}\left(\omega_{\mathrm{p}} \mathrm{R}_{\mathrm{pe}}^{2}+\left[\frac{\mathrm{R}_{\mathrm{pe}} \tan \beta_{\mathrm{pe}}}{\mathrm{A}_{\mathrm{pe}}}-\frac{\mathrm{R}_{\mathrm{te}} \tan \beta_{\mathrm{te}}}{\mathrm{A}_{\mathrm{te}}}\right] \mathrm{Q}-\mathrm{R}_{\mathrm{te}}^{2} \omega_{\mathrm{t}}\right)
$$

The turbine torque yields to:

$$
\mathrm{T}_{\mathrm{t}}=\omega_{\mathrm{p}}^{2} \rho \mathrm{R}_{\mathrm{pe}}^{3} \mathrm{~A}_{\mathrm{pe}} \mathrm{C}_{\mathrm{f}}\left(1+\mathrm{C}_{\mathrm{f}} \tan \beta_{\mathrm{pe}}-\frac{\lambda_{\mathrm{r}}}{\lambda_{\mathrm{a}}} \mathrm{C}_{\mathrm{f}} \tan \beta_{\mathrm{te}}-\lambda_{\mathrm{r}}^{2} \mathrm{SR}\right)
$$

Therefore, the torque converter torque ratio can be expressed as:

$$
\mathrm{TR}=\frac{1+\mathrm{C}_{\mathrm{f}} \tan \beta_{\mathrm{pe}}-\mathrm{C}_{\mathrm{f}} \lambda_{\mathrm{r}} / \lambda_{\mathrm{a}} \tan \beta_{\mathrm{te}}-\lambda_{\mathrm{r}}^{2} \mathrm{SR}}{1+\mathrm{C}_{\mathrm{f}} \tan \beta_{\mathrm{pe}}-\mathrm{C}_{\mathrm{f}} \lambda_{\mathrm{r}} / \lambda_{\mathrm{a}} \tan \beta_{\mathrm{se}}}
$$

Where SR is the speed ratio and it is equal to $\omega_{t} / \omega_{p}$. The efficiency of torque converter unit in the converter system is determined by the following equation:

$$
\eta=\mathrm{TR} \times \mathrm{SR}
$$

The output speed, $\mathrm{y}_{2}$, of the first layout is expressed as:

$$
\mathrm{y}_{2}=\frac{\omega_{\mathrm{p}}}{1+\mathrm{J}}\left[\frac{1}{1+1 / \mathrm{K}}+\mathrm{SR} \mathrm{J}\right]
$$

Where $y_{2}$ is speed of the arm in the planetary gear member when the train is locked, SR is the speed ratio defined as the ratio of the rotational speed 
of the turbine to that of the pump, $K=n_{S p} / n_{R p}, J=n_{S t} / n_{R t}$ in which $n$ is the number of teeth, the subscripts $\mathrm{S}$ and $\mathrm{R}$ are the sun and ring gears. The output speed of the second layout is expressed as:

$$
\omega_{\mathrm{Rt}}=\omega_{\mathrm{p}}[\mathrm{K}-\mathrm{JSR}-\mathrm{K} \mathrm{J}]
$$

Therefore, the efficiency of the present system is written as:

$\eta=\frac{\text { Power trasferedmechanicaly }+ \text { Powetransferd through } \text { ørqueconverter }}{\text { Inputpower }}$

Where the power transferred mechanically is the bypassed power that equals to the input power minus that transferred by the torque converter. The power transferred by the torque converter is equal the turbine torque times its angular velocity. The efficiency $(\eta)$, TR and VR of the whole torque converter system are:

$$
\eta=\frac{T_{a} y_{2}}{T_{p} \omega_{p}} \quad, \quad T R=\frac{T_{a}}{T_{p}} \quad, \quad V R=\frac{y}{\omega_{p}}
$$

\section{Simulation Parameters and Considerations}

All the simulated results performed at engine rpm equals 1600. Simulations deal with present model validity, present system performance, assessment and merits. For model validity, the simulated results of the present model using Eq. 9 are compared with the previous experimental results of conventional torque converter Kaihua et al ${ }^{[2]}$ and Yang et al. ${ }^{[4]}$. The dimensions and specifications of such torque converter are in Tables 1 and 2.

\begin{tabular}{|c|c|c|c|c|c|c|}
\hline & \multicolumn{2}{|c|}{ Pump } & \multicolumn{2}{|c|}{ Turbine } & \multicolumn{2}{|c|}{ Reactor } \\
\hline & Entrance & exit & Entrance & exit & Entrance & exit \\
\hline Number of vanes & \multicolumn{2}{|c|}{22} & \multicolumn{2}{|c|}{24} & \multicolumn{2}{|c|}{20} \\
\hline $\begin{array}{l}\text { Wheel radius } \\
(\mathrm{mm})\end{array}$ & 138.9 & 199.9 & 202.2 & 138.9 & 129.9 & 129.9 \\
\hline $\begin{array}{l}\text { Width of flow } \\
\text { path }(\mathrm{mm})\end{array}$ & 36.5 & 26.5 & 25.7 & 36.5 & 40 & 40 \\
\hline $\begin{array}{l}\text { Thickness of the } \\
\text { vanes }(\mathrm{mm})\end{array}$ & 3 & 3.7 & 4 & 2 & 5.4 & 2.5 \\
\hline Angle of vanes $\left({ }^{\circ}\right)$ & 129 & 95 & 36 & 155 & 124 & 27 \\
\hline $\begin{array}{c}\text { Spread length of } \\
\text { vanes }(\mathrm{mm})\end{array}$ & \multicolumn{2}{|c|}{87.5} & \multicolumn{2}{|c|}{132.5} & \multicolumn{2}{|c|}{86.5} \\
\hline
\end{tabular}

Table 1. Torque converter dimensions used in Kaihua et al. ${ }^{[2]}$. 
Table 2. Geometry parameters of hydraulic torque converter, Yang et al. ${ }^{[4]}$.

\begin{tabular}{|c|c|c|c|c|c|c|}
\hline \multirow{2}{*}{$\begin{array}{c}\text { Torque converter } \\
\text { parameters }\end{array}$} & \multicolumn{2}{|c|}{ Pump } & \multicolumn{2}{|c|}{ Turbine } & \multicolumn{2}{|c|}{ Reactor } \\
\hline & Entrance & exit & Entrance & exit & Entrance & exit \\
\hline Amount of vanes & \multicolumn{2}{|c|}{22} & \multicolumn{2}{|c|}{24} & \multicolumn{2}{|c|}{20} \\
\hline $\begin{array}{l}\text { Wheel radius } \\
(\mathrm{mm})\end{array}$ & 78.2 & 129.9 & 129.9 & 69.3 & 69.3 & 78.2 \\
\hline Angle of vanes $\left(^{\circ}\right)$ & -16.5 & -6 & 49.5 & -57.5 & 16.5 & 72 \\
\hline
\end{tabular}

It is notable that the blade angles in Table 1 are measured from the horizontal direction while in Table 2 are measured from the vertical direction. After model validity, performance assessment and merits will be demonstrated. Comparison is performed between the present power transmission system and automatic transmission Yang et al. ${ }^{[4]}$. In this case, assessment is achieved on the basis that the torque converter of Kaihua et $a .^{[2]}$ is installed in the present power transmission system. Consequently, the gear ratios of the present system have to be assigned. For the first and second configurations, planetary gear data are stated in Table 3. In the two configurations, the number of teeth for the corresponding gears is the same. Additionally, the second configuration output is connected to a reduction gear with a gear ratio of 1.428:1. Kinetics and model can therefore be used to assess the present power transmission system.

Table 3. Kinematics of the two planetary gear configurations.

\begin{tabular}{|c|c|c|c|c|}
\hline $\begin{array}{c}\text { Gear } \\
\text { type }\end{array}$ & $\begin{array}{c}\text { Housing } \\
\text { sun }\end{array}$ & Housing ring & $\begin{array}{c}\text { Turbine } \\
\text { sun }\end{array}$ & $\begin{array}{c}\text { Turbine } \\
\text { ring }\end{array}$ \\
\hline Number of teeth & 20 & 40 & 30 & 50 \\
\hline
\end{tabular}

\section{Results and Discussion}

Figures 5 and 6 illustrate the present simulated results of the torque ratio and efficiency against the speed ratio by using equations $(9 \& 10)$, respectively. Comparison is made with the experimental results Kaihua et $a l .{ }^{[2]}$ and Yang et al. ${ }^{[4]}$. These plots display good matching between the simulated results of the present model and the experimental results. This denotes the capability of the present model to predict acceptably the performance of the torque converter at different conditions.

Figure 7 illustrates the performance map for the power transmission system showing the torque ratio and the efficiency lines. The figure depicts the efficiency lines at different values of $m$ (Ratio of 
power portion transferred mechanically to the input power controlled by vane couplings). This enables the operation in a band of torque ration and efficiencies. Moreover, this will sacrifice the torque converter torque fluctuations damping effect. Nevertheless, the variable capacity inherent

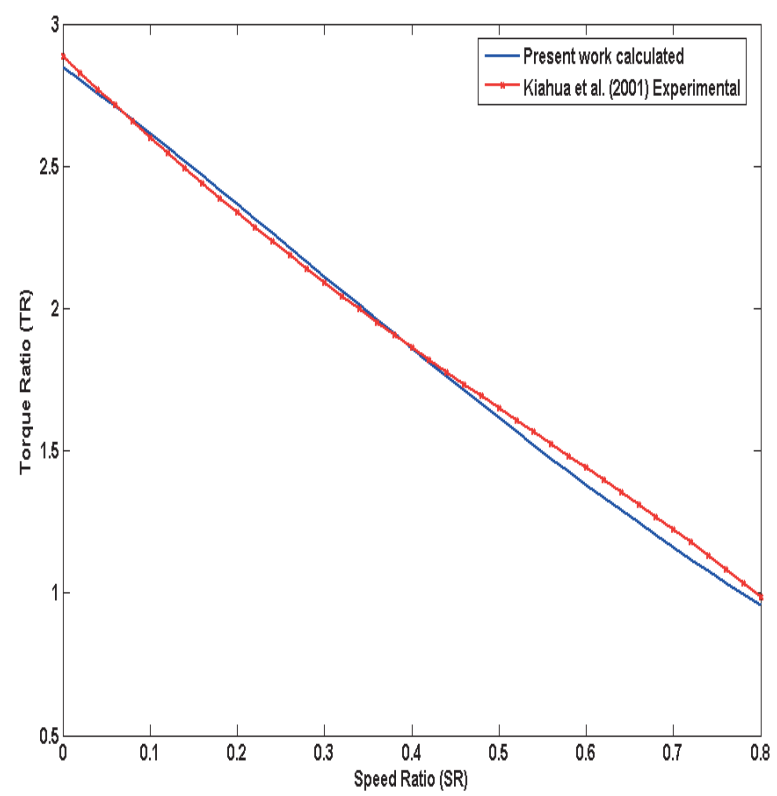

Fig. 5. Model validation with the experimental results, Kaihua et al. ${ }^{[2]}$.

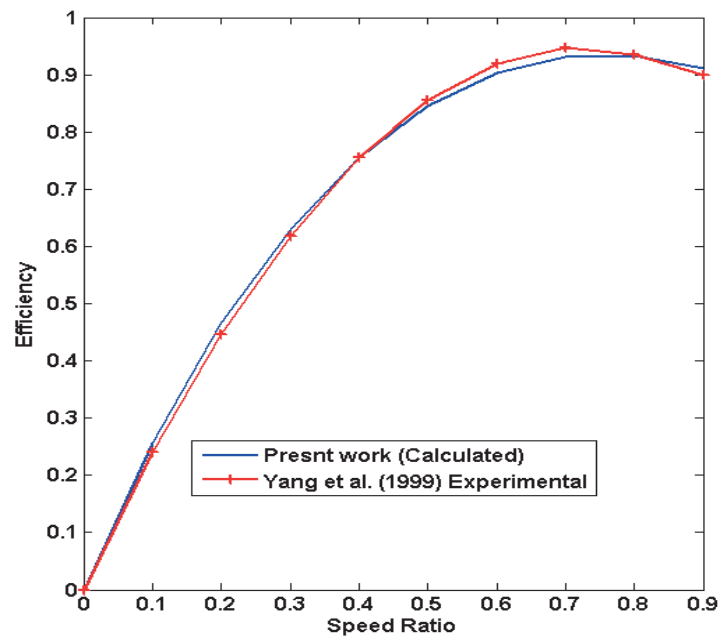

Fig. 6. Model validation with the experimental results, Yang et al. ${ }^{[4]}$. 
in the present system will give full control to the equipment user and the flexibility selection according to loads and demands. At a defined speed ratio, a switching can be done from torque converter operation to the power split modes with variable power ratio path. It is notable that the choice of $m$ value is varying according to the load requirements and the best efficiency. This figure illustrates the three operational zones. In the first zone, torque is represented by the operation of the torque converter is directly connected with a reduction gear for starting demand. In the second zone, it is represented by the operation of the first configuration and finally the third zone is the second configuration operating range.

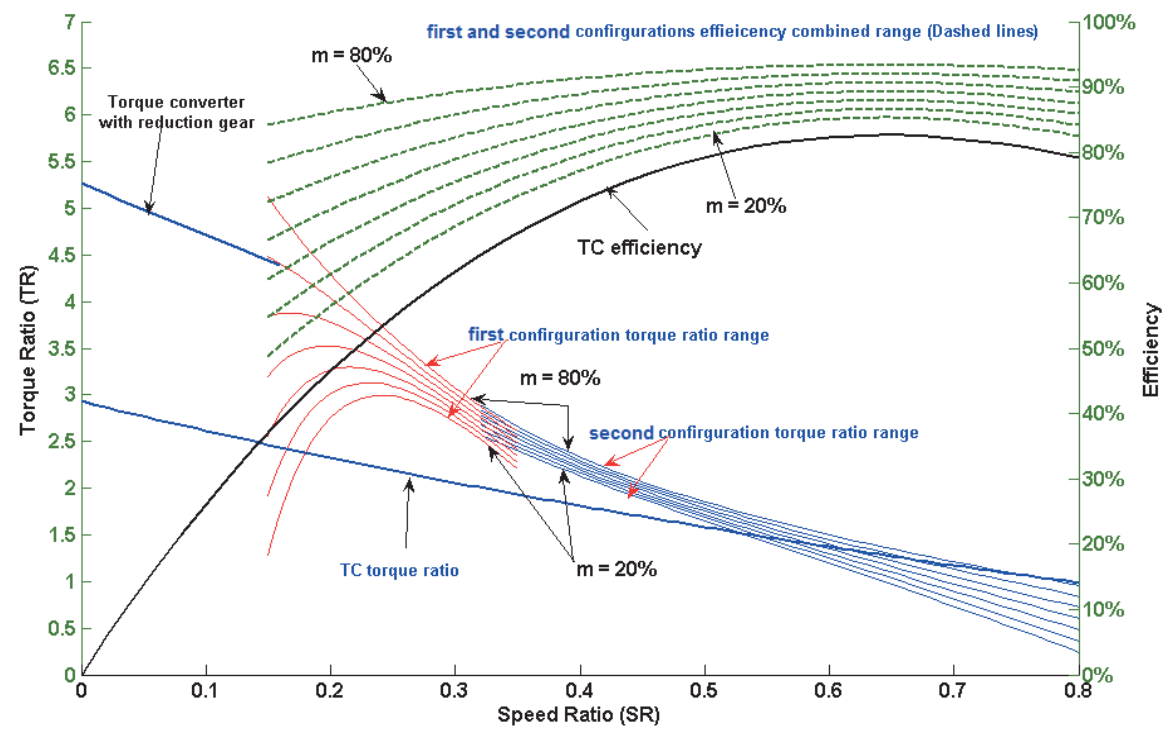

Fig. 7. Present system performance map.

Figure 8 demonstrates the operating for the torque converter with and without the splitting concept. In case of operating without splitting concept, the pump blade exit angle alters significantly the torque ratios especially at lower speed ratios. Nonetheless, changing the angle effect has insignificant influence for the operation of the torque converter with the power splitting concept.

Figure 9 illustrates a five speed automatic transmission traction curve at full throttle engine map. Full calculation of transmission traction curve is demonstrated in Saleh ${ }^{[14]}$. The traction curves are plotted against the vehicle speed for different gear ratios of the transmission. The performance map is determined by calculating the absorbed torque that 
the pump can extract from the engine Equation 5. Therefore, the turbine torque can be calculated for different SR. Consequently, with the knowledge of gear ratios and final drive gear ratio the overall performance map is assigned for different gear shifts. The traction diagram also illustrates the vehicle running resistance due to rolling, grade and air resistances while running. The main feature of the automatic transmission map is the traction of each gear ratio does not coincide with the required traction for the vehicle. Consequently, a larger number of gear ratios are needed to close the shifting gap. It is worth to mention that, the resistance line obliges the transmission to operate in either different gear ratio or changing the throttle position to meet the required traction.

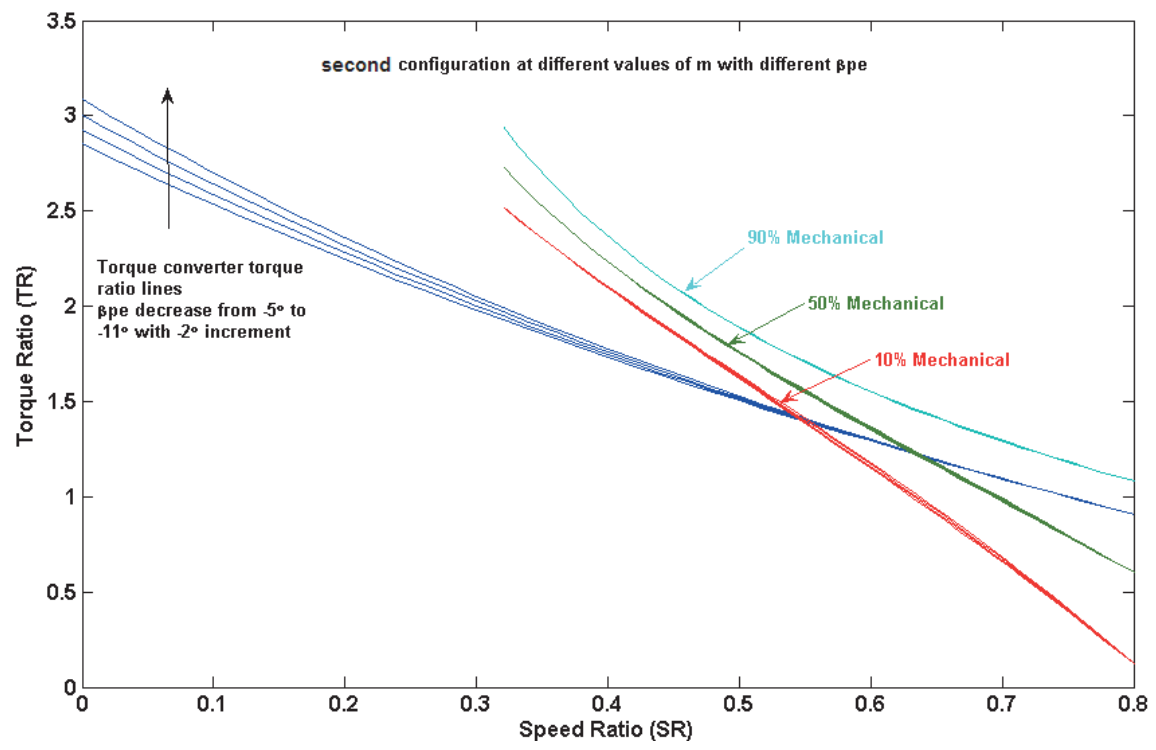

Fig. 8. Effect of pump blade exit angle on second configuration.

Figure 10 represents the performance map of the present system when installed in the passenger vehicle instead of the automatic transmission. Operation of the present system is achieved at full load, full throttle engine map. Unlike the automatic transmission, this system offers an operational band for each engine speed. This band is established through changing the $\mathrm{m}$ value from $\mathrm{m}$ equals 0.2 to 0.8 . Moreover, changing the vehicle speed will cover the whole area of the demand traction. This feature of the present system has a superior performance than the automatic transmission. It can be seen from the plot that the 
present system is operating between two limits that represent the vehicle performance at minimum and maximum engine speeds. Additionally, these operating limits cover a larger area than the automatic transmission that operates at fixed gear ratio lines in the performance map. This area is the confined between the upper operating line of the upper limit and the lower operating line of the lower limit. This is conversely to the operation of the automatic transmission that offers a single operating line for every gear ratio over the engine speed limits. Moreover, no transmission gap is observed in the present system since it acts as continuously variable transmission.

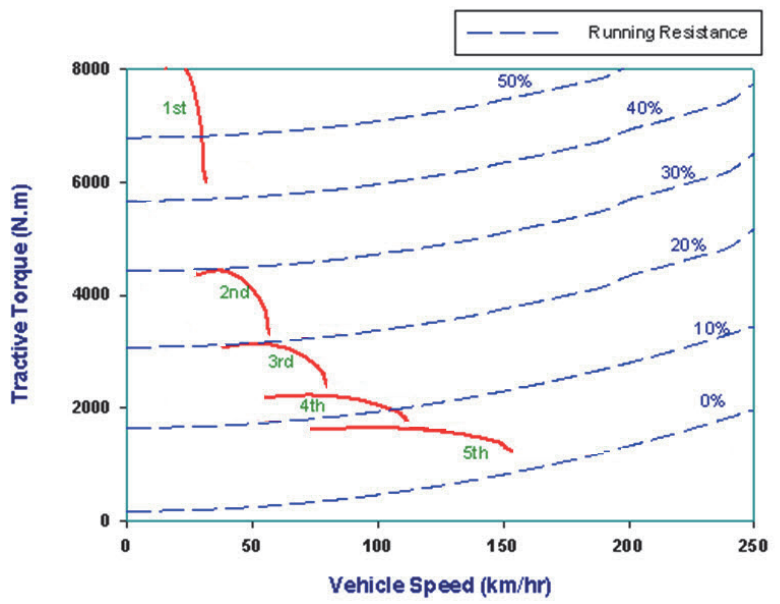

Fig. 9. Passenger vehicle automatic transmission performance Saleh ${ }^{[14]}$.

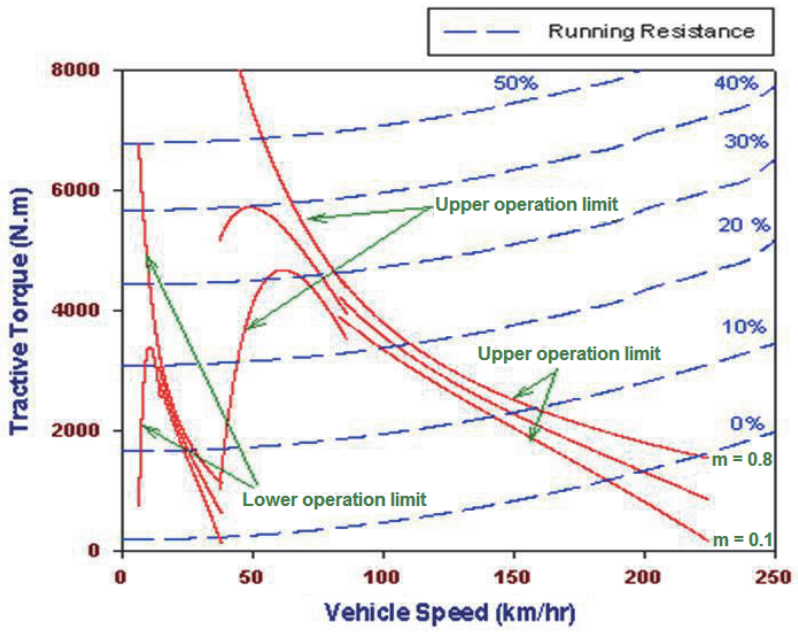

Fig. 10. The present system performance. 


\section{Conclusions}

From this work, the following conclusions are drawn:

1. The present work introduces power transmission system that operates with power splitting concept.

2. This system composed of conventional torque converter connected to planetary sets. Three clutches are used to shift the operating modes and two vane couplings are utilized to regulate power in power paths.

3. Vane coupling is characterized by extremely compactness that controls the torque the power paths.

4. The present work introduces a validated model and is utilized with planetary gear kinematics to illustrate the present transmission system performance.

5. The simulated results demonstrate that it is insignificant to enhance the torque converter when operates with the power splitting.

6. Unlike the automatic transmission that offers a single operating line for every gear ratio over the engine speed, this system offers an operational band for each engine speed.

7. The present system act as a continuously variable transmission with variable power split ratio.

\section{Nomenclature}

A Area $\left[\mathrm{m}^{2}\right]$

$\mathrm{C}_{\mathrm{f}} \quad$ Flow coefficient [---]

$\mathrm{g} \quad$ Gravitation acceleration $\left[\mathrm{m} / \mathrm{s}^{2}\right]$

I and $\mathrm{J}$ Teeth ratios used in Eqs. 10 and 11 [---]

$\mathrm{m}$ Ratio of power portion transferred mechanically to the input $\mathrm{N}$ power [---]

Q Number of teeth [---]

$\mathrm{R} \quad$ Flow rate inside the torque converter $\left[\mathrm{m}^{3} / \mathrm{s}\right]$

SR Radius [m]

$\mathrm{T}$ Speed ratio; ratio of the rotational speed of the turbine to the

TR pump [---]

$\mathrm{X}$ Torque [Nm]

y Torque ratio; torque of the output member to that of the input [---] 
Speed of the sun gear while the arm is fixed [rotation/sec]

Speed of the locked planetary gears [rotation/sec]

\section{Symbols}

$\begin{array}{ll}\alpha & \text { Absolute flow angle [Degree] } \\ \beta & \text { Blade angle [Degree] } \\ \eta & \text { Efficiency of the torque converter system [--- } \\ \rho & \left.\text { Oil density [kg/ }{ }^{3}\right] \\ \omega & \text { Angular velocity [rad } / \mathrm{s}] \\ \lambda_{\mathrm{a}} & \text { Area ratio [--- }] \\ \lambda_{\mathrm{f}} & \text { Radius ratio [--- }]\end{array}$

\section{Subscript}

$\begin{array}{ll}\mathrm{e} & \text { exit } \\ \mathrm{m} & \text { Mechanical } \\ \mathrm{r} & \text { Ring } \\ \mathrm{s} & \text { Sun or stator } \\ \mathrm{p} & \text { Pump } \\ \mathrm{t} & \text { Turbine }\end{array}$

\section{References}

[1] Eksergian, R., "The fluid torque converter and coupling", Journal of the Franklin Institute, 235: 410-478 (1943).

[2] Kaihua, Y., Qingdong, Y. and Muqiao, Z., "Computational aided calculation of hydraulic torque converter original characteristic", Proceeding of the Fifth International Conference on Fluid Power Transmission and Control, 4: 533-536 (2001).

[3] Dong, Y., Korivi, V., Attibele, P. and Yuan, Y., "Torque converter CFD engineering Part I: Torque ratio and $\mathrm{K}$ factor improvement through stator modifications", Transmission and Driveline Systems Symposium, (SP-1655), SAE, World Congress Detroit, Michigan, March 4-7, (2002).

[4] Yang, S., Shin, S., Bae, I. and Lee, T., “A Computer-Integrated Design Strategy for Torque Converter Using Virtual Modeling and Computational Flow Analysis", SAE Technical paper series 1999-01-1046.

[5] Wei, W. and Qingdong, Y., "Study on Hydrodynamic Torque Converter Parameter Integrated Optimization Design System Based on Tri-Dimensional Flow Field Theory", SAE Technical paper series 2008-01-1525.

[6] Song, K., Kim, K., Park, J., Kook, J., Oh, J., Cho J. and Kim, M., "Development of the Integrated Process for Torque Converter Design and Analysis", SAE Technical paper series 2008-01-0785.

[7] Abd El-Maksoud, R.M., "Controlled Power Splitting and Combining Transmission (CPSCT)", World Intellectual Property Organization, WIPO, Number WO 00/71905, (2000). 
[8] Lu, Z., "Acceleration simulation of a vehicle with a continuously variable power split transmission", M.Sc., Morgantown, West Virginia, College of Engineering and Mineral Resources, West Virginia University, (1998).

[9] Shellenberger, M.J.C., "Design considerations for variable power split hydraulic drives for industrial applications", M.Sc. Department of Mechanical and Aerospace Engineering, College of Engineering and Mineral Resources, West Virginia University, (1999).

[10] Setlur, P., Wagner, J.R., Dawson, D.M. and Samuels, B., "Nonlinear control of a continuously variable transmission (CVT)", Control Systems Technology, IEEE Transactions, 11 (1): 101-108 (2003).

[11] Fox, A.J., "Design and analysis of a modified power split continuously variable transmission", Ph.D., College of Engineering and Mineral Resources, West Virginia University, (2003).

[12] Gomez, M.M., "A continuously variable power-split transmission in a hybrid-electric sport utility vehicle", M.Sc., College of Engineering and Mineral Resources at West Virginia University, Morgantown, West Virginia (2003).

[13] Miller, J.M., "Hybrid electric vehicle propulsion system architectures of the e-CVT type", IEEE Transactions on Power Electronics, 21(3): 756-767 (2006).

[14] Saleh, M.A. "Enhancement of torque converter performance using splitting power concept", M.Sc., Faculty of Engineering, Mataria, Helwan University, Cairo (2009). 


\section{نظام متقدم لناقل القدرة}

\section{رافع محمد عبد المقصود، ونزيه نعمان بيومي'، ومحمد أحمد صالح'}

كلية الهندسة بالمطرية، جامعة حلوان، القاهة، جههورية مصر العربية،

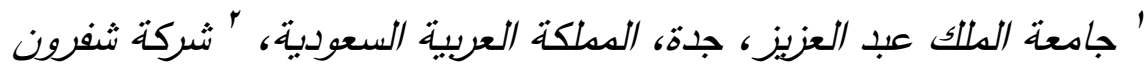

مصر للزبوت، القاهرة، جههوبية مصر العربية

المستخلص. تستخدم البحوث المختلفة في تعديل وتحسين ناقل القدرة

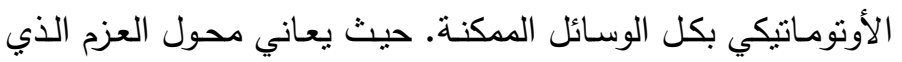

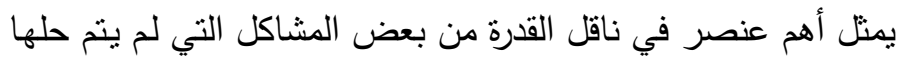

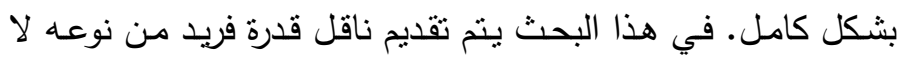

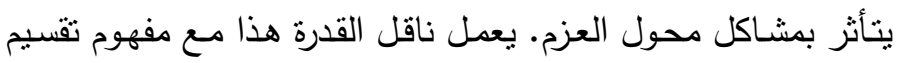

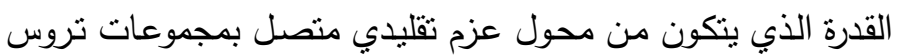

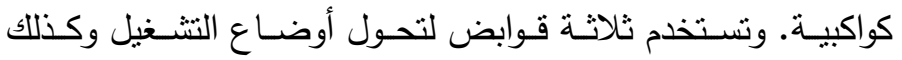

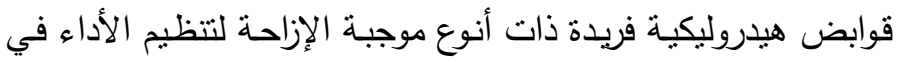

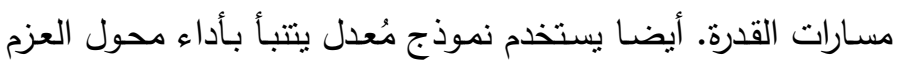

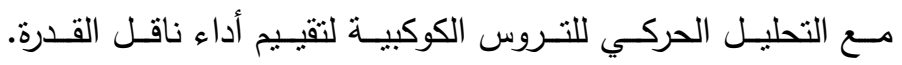
بالإضافة إلي ذللك فإن النظام الحالي يعمل بأداء عالٍ. ويعمل النظام

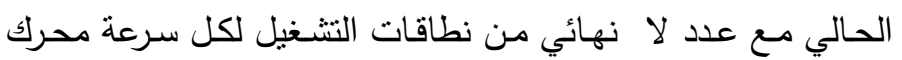
خلافاً للناقل الاوتومانيكي الذى يكون أداؤه خطباً. 